Vol. 14 (2005): 57-69.

\title{
A comparison of nitrogen and carbon reserves in acid sulphate and non acid sulphate soils in western Finland
}

\author{
Maija Paasonen-Kivekäs \\ Helsinki University of Technology, Laboratory of Water Resources, PO Box 5200, \\ FI-02015 HUT, Finland,e-mail: maija.paasonen@hut.fi \\ Markku Yli-Halla \\ MTT Agrifood Research Finland, FI-31600 Jokioinen, Finland
}

\begin{abstract}
Previous studies suggest that nitrogen (N) loads from acid sulphate soil (AS soil) catchments in Finland are higher than those from other agricultural catchments. This study seeks to explain this difference by measuring carbon (C) and N profiles in both an AS soil and a neighbouring non AS soil. In Lapua, western Finland, two adjacent fields (Dystric Cambisols), subjected to similar agricultural practices, were analysed to the depth of $240 \mathrm{~cm}$ for $\mathrm{pH}$, total $\mathrm{C}\left(\mathrm{C}_{\text {tot }}\right)$, total $\mathrm{N}\left(\mathrm{N}_{\text {tot }}\right), \mathrm{NH}_{4}{ }^{+}-\mathrm{N}, \mathrm{NO}_{3}{ }^{-} \mathrm{N}$, sulphur and bulk density. Field $\mathrm{A}$, an AS soil, contained sulfidic materials and $0.9 \% \mathrm{C}_{\text {tot }}$ below $170 \mathrm{~cm}$, while Field B, not an AS soil, had $0.3 \%$ $\mathrm{C}_{\text {tot }}$ in the subsoil and no sulfides. In these soils, the groundwater level declined below $200 \mathrm{~cm}$ in summer, subjecting the subsoil to oxidation. This study revealed large stocks of $\mathrm{C}_{\mathrm{tot}}, \mathrm{N}_{\mathrm{tot}}$, and mineral $\mathrm{N}$ in the subsoil, particularly in the AS soil. At 20-240 cm, Field A contained 292 tons of $\mathrm{C}_{\text {tot }}$ ha ${ }^{-1}$ and 25 tons of $\mathrm{N}_{\text {tot }}$ ha ${ }^{-1}$, while Field B had 152 tons of $\mathrm{C}_{\text {tot }}$ ha $^{-1}$ and 11 tons of $\mathrm{N}_{\text {tot }}$ ha $^{-1}$. Field A contained up to $435 \mathrm{~kg}$ of mineral $\mathrm{N} \mathrm{ha}^{-1}$ in autumn, while in Field $\mathrm{B}$ there was only up to $137 \mathrm{~kg}$ of mineral $\mathrm{N} \mathrm{ha}^{-1}$. In Field $\mathrm{A} \mathrm{NH}_{4}{ }^{+} \mathrm{N}$ dominated strongly, while $\mathrm{NO}_{3}^{-}-\mathrm{N}$ dominated in Field $\mathrm{B}$. It is suggested that the greater concentration of mineral $\mathrm{N}$ in the AS soil is due to 1) a greater stock of total (mineralizable) $\mathrm{N}$ and 2) the slower rate of nitrification resulting in substantial $\mathrm{NH}_{4}^{+}-\mathrm{N}$ retention on cation exchange sites.
\end{abstract}

Key words: carbon, nitrogen, nitrification, mineralization, organic matter, acid sulphate soils, subsoil, drainage

\section{Introduction}

Soils developed in materials sedimented in lakes and small bays of the sea often contain plenty of organic matter in the subsoil. Organic matter originates from the biota of the water and has been thoroughly mixed with the mineral matter, mostly fine or medium textured. In the Nordic countries, these mud materials are traditionally called gyttja 
Paasonen-Kivekäs, M. \& Yli-Halla, M. N and C reserves in acid sulphate and non acid sulphate soils

(e.g., Wiklander et al. 1950) and they closely resemble the limnic materials of Soil Taxonomy (Hansen 1959). They often contain substantial amounts of sulphur (S), accumulated as iron sulfides in the sediment under reducing conditions. The parent material of acid sulphate soils (AS soils), which was deposited predominantly during the Litorina period (7500-3000 BP) in the Baltic basin, is a typical example of these soils, occurring particularly on the western coast of Finland (Purokoski 1958, Erviö 1975). These former sediments have been brought into an oxidized environment by the isostatic land uplift and agricultural drainage. Small shallow lakes and wetlands have also been drained to serve as agricultural land. According to the FAO system (FAO 1988), these soils are commonly classified as Gleysols (Öborn 1989, Yli-Halla 1997, Joukainen and Yli-Halla 2003), while the best-drained ones are also classified as Cambisols (Öborn 1989).

Inventories of carbon (C) in soil and lake sediments have recently been carried out in Finland, resulting in estimates of that element in forest soils (Kauppi et al. 1997, Liski and Westman 1997), in peatlands (Minkkinen 1999) and lake sediments (Kortelainen and Pajunen 2000). For agricultural lands, there are plenty of data on the $\mathrm{C}$ content in the plough layer but fewer dealing with the subsoil. Inaccurate information about the areas of the different soil types also contributes to the fact that a detailed inventory of $\mathrm{C}$ in Finnish agricultural soils is still missing.

In organic forms, $\mathrm{C}$ and nitrogen $(\mathrm{N})$ are intimately linked. In mineral soils, over $95 \%$ of the total nitrogen $\left(\mathrm{N}_{\mathrm{tot}}\right)$ is generally contained in soil organic matter. The major part of these $\mathrm{N}$ reserves is usually in the top layer due to accumulation of crop residues and humus. Investigations of AS soils (Wiklander et al. 1950, Öborn 1989, Yli-Halla 1997, Bärlund et al. 2004) have indicated a high content of $\mathrm{N}_{\text {tot }}$ in the subsoil also. This $\mathrm{N}$ stock is potentially subjected to mineralization, which is controlled by several factors, such as composition of the substrates, soil temperature, moisture and $\mathrm{pH}$. Mineral $\mathrm{N}$ fractions, ammonium nitrogen $\left(\mathrm{NH}_{4}{ }^{+} \mathrm{N}\right)$ and especially nitrate nitrogen $\left(\mathrm{NO}_{3}{ }^{-} \mathrm{N}\right)$ are liable to leaching via subsurface drainage flow or deep percolation of groundwater. Indeed, within the Finnish network of small representative catchments, the $\mathrm{N}$ load from catchments with AS soils has been observed to be higher than the loads from other agricultural catchments in Finland (Rekolainen 1989, Vuorenmaa et al. 2002).

This study seeks to explore the origins of this increased $\mathrm{N}$ load by comparing soil profile concentrations of $\mathrm{C}$ and $\mathrm{N}$ to depths of $240 \mathrm{~cm}$ in an AS soil and a neighbouring non AS soil, both under crops, in western Finland. The aims of the study were (1) to investigate the vertical distribution of $\mathrm{C}$ and $\mathrm{N}_{\text {tot }}$ and mineral nitrogen $\left(\mathrm{N}_{\text {min }}\right)$ reserves in an AS soil compared with a non AS soil and (2) to evaluate the role of native organic matter as a source of $\mathrm{N}_{\text {min }}$. Concentrations of $\mathrm{N}_{\min }$ in AS soils have not been published before; this is the first study to monitor $\mathrm{N}_{\text {min }}$ below $120 \mathrm{~cm}$ in any Finnish agricultural soil. This study contributes to our knowledge of the stock and distribution of $\mathrm{N}$ and $\mathrm{C}$ in AS soils. This basic information is needed for a more detailed understanding of the observed net transport of $\mathrm{N}$ to watercourses and to develop sound management practices for AS soils, as well as to assess the impacts of different practices involving these soils.

\section{Material and methods}

\section{Study site}

The experimental site is located at Lapua $\left(62^{\circ} 51^{\prime} \mathrm{N}\right.$, $23^{\circ} 15^{\prime} \mathrm{E}$ ) in Ostrobotnia, western Finland (Fig. 1). The site is $60-62 \mathrm{~m}$ above the sea level and the surface slope is about $1 \%$. The study was carried out for two field sections (Fields A and B), which have separate subsurface drainage systems. The distance between the experimental areas is about $100 \mathrm{~m}$. The area of Field A is 2.47 ha and that of Field B is 0.59 ha. The soil texture is fine sand to a depth of about $0.5 \mathrm{~m}$, while deeper horizons consist of silt. The clay content of the top layer (0-30 $\mathrm{cm}$ ) is $11-15 \%$, increasing downwards to $27-29 \%$ at the depth of $50-100 \mathrm{~cm}$. 
Vol. 14 (2005): 57-69.

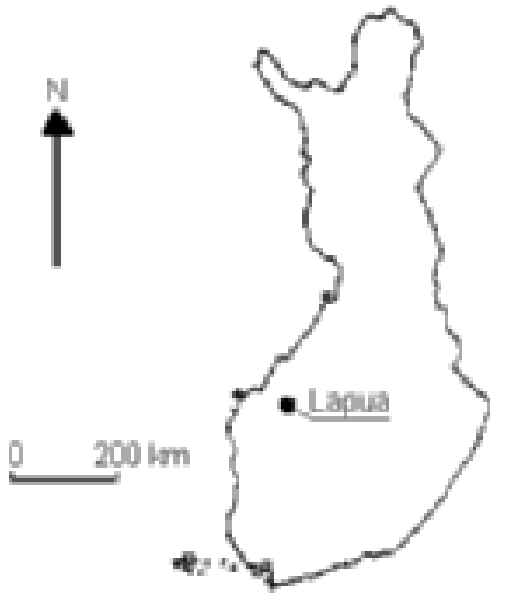

Fig. 1. Location of the Lapua study area in western Finland.

Drainage of the fields was accomplished with open ditches in the 1960s and with subsurface drainage pipes in the early 1970s. The drain depth in Field A varies from 1.0 to $1.5 \mathrm{~m}$. The field drains discharge into a main collector pipe having an outlet to a main ditch flowing between the fields. In Field B, the drain depth is about $1 \mathrm{~m}$ and the drains discharge directly to the main ditch. The initial drain spacing was $20 \mathrm{~m}$, but the spacing was halved to $10 \mathrm{~m}$ in spring 1993 for a controlled drainage experiment.

The crop was mainly starch potato (Solanum tuberosum, L.) several years before and during the study period. The annual $\mathrm{N}$ fertilizer rate was 70 $83 \mathrm{~kg} \mathrm{ha}^{-1}$. No manure or other types of organic fertilizers were applied. Agricultural practices in the two fields were the same and representative of those employed in the region.

\section{Soil sampling and groundwater observations}

Soil sampling and monitoring of groundwater level were carried out during the period 1994-1996. The soils were sampled down to $240 \mathrm{~cm}$ taking samples at $20-40 \mathrm{~cm}$ increments with a $25 \mathrm{~mm}$ diameter manual drill. Upon sampling, the soil was sealed in airtight plastic containers, which were stored in cool boxes. The sampling dates were 1) after snowmelt and before fertilization in May and 2) after harvest in November. The number of sampled profiles was 1-3 per field and date. The total number of profiles sampled was 10 for Field $A$ and 7 for Field B.

The depth of the water table was recorded in observation wells in each field in the middle of two drain lines. There were twelve wells in total, with depths ranging from 1.6 to $2.5 \mathrm{~m}$. The wells were made of $30 \mathrm{~mm}$ diameter PVC pipe surrounded by a filter. Manual observations using a graded waterdetecting gauge were carried out on a two-to-fourweek basis. Furthermore, automatic pressure sensors (Jensen Ltd. Type PSL) with a 15-min measurement interval were installed in three wells in Field A. Due to technical problems, continuous water table data series were not achieved. The field site and measurements have been described in more detail by Paasonen-Kivekäs et al. (1997).

\section{Soil analyses}

Mineral $\mathrm{N}$ was determined from all sampled profiles. The soil samples, stored at $+4^{\circ} \mathrm{C}$, were analyzed within 3-4 days after sampling. Ten grams of fresh soil was extracted by shaking with $50 \mathrm{ml}$ of 2 $\mathrm{M} \mathrm{KCl}$ for $1 \mathrm{~h}$. The suspension was centrifuged for 5 min and then filtered using a Schleicher \& Schuell 595 filter. The concentrations of $\mathrm{NO}_{3}^{-}-\mathrm{N}^{-}$and $\mathrm{NH}_{4}{ }^{+}-$ $\mathrm{N}$ in the extract were measured by a flow injection analyser (Tecator, FIAstar 5010 Analyzer) according to the Tecator Application Notes ASN 65-31/84 and ASN 65-32/84 (Emteryd 1989). The contents of $\mathrm{NO}_{3}^{-}-\mathrm{N}$ and $\mathrm{NH}_{4}^{+}-\mathrm{N}$ were calculated as $\mathrm{mg} \mathrm{g}^{-1}$ of dry soil. Water content in the fresh soil samples was determined gravimetrically by drying at $105^{\circ} \mathrm{C}$. The soil samples were analysed for $\mathrm{pH}\left(\mathrm{H}_{2} \mathrm{O}\right)$ in the field immediately after sampling (MacLean 1984; pH meter ORION SA 520).

Total S $\left(\mathrm{S}_{\mathrm{tot}}\right), \mathrm{C}_{\text {tot }}$ and $\mathrm{N}_{\text {tot }}$ were determined using air dry samples taken in May 1994. These concentrations were assumed to be so stable that they were determined only once from three soil profiles from Field A and two from Field B. A Leco CN 
Paasonen-Kivekäs, M. \& Yli-Halla, $M . N$ and $C$ reserves in acid sulphate and non acid sulphate soils

2000 dry combustion analyzer was used for the determination of $\mathrm{C}_{\text {tot }}$ and $\mathrm{N}_{\text {tot }}$. The detection limit (blank mean $+3 \times$ standard deviation of the blanks), calculated on the basis of the results over a long time, is $0.12 \%$ and $0.09 \%$ for $\mathrm{C}_{\text {tot }}$ and $\mathrm{N}_{\text {tot }}$, respectively. Mean deviation between the two replicates of each sample was on average $1.5 \%$ for $\mathrm{C}_{\text {tot }}$ and $3.2 \%$ for $\mathrm{N}_{\text {tot }}$. All C was assumed to be organic. Total $\mathrm{S}$ was digested with concentrated $\mathrm{HNO}_{3}$ (SFS 3044) and determined by plasma emission spectroscopy. Subsoil samples $(110-240 \mathrm{~cm})$ were tested for the presence of sulfidic materials by the method of Soil Survey Staff (1999) using an aerobic incubation of 8 weeks. After incubation, the $\mathrm{pH}\left(\mathrm{H}_{2} \mathrm{O}\right)$ was determined and sulphate sulphur $\left(\mathrm{SO}_{4}{ }^{2-}-\mathrm{S}\right)$ was extracted from the soil samples with $0.01 \mathrm{M} \mathrm{CaCl}_{2}$ and determined by plasma emission spectroscopy. Mean deviation between the two replicates was on average $1.5 \%$ for $\mathrm{SO}_{4}{ }^{2-}-\mathrm{S}$ and $1.8 \%$ for $\mathrm{S}_{\text {tot }}$.

Bulk density (BD) was determined for the depths $0-30 \mathrm{~cm}, 40-50 \mathrm{~cm}$ and $60-70 \mathrm{~cm}$ by the core sampling method (Blake 1985a). Bulk density for deeper horizons was calculated on the basis of $\mathrm{C}$ content using the formula presented by Howard et al. (1995): $\mathrm{BD}=1.3-(0.275 \times \log \mathrm{C} \%)$. Particle density was measured employing a pycnometer (Blake 1985b). Porosity was calculated from the BD and particle density (Vomocil 1985). Total porosity of the plough layer was about 55 vol-\% in both fields. The porosity of the silty subsoil below the fine sand layer was about 51 vol- $\%$ in Field A and about 48 vol- $\%$ in Field B.

The concentrations of $\mathrm{C}_{\text {tot }}, \mathrm{N}_{\text {tot }}, \mathrm{NO}_{3}^{-}-\mathrm{N}$ and $\mathrm{NH}_{4}{ }^{+}-\mathrm{N}$ were converted to quantities, expressed as $\mathrm{kg} \mathrm{ha}^{-1}$, for the individual soil layers using the BD values. The measured $B D$ values were used for the upper three layers and the estimated values (Howard et al. 1995) for the deeper ones. The amount of $\mathrm{N}_{\min }$ was calculated as the sum of $\mathrm{NO}_{3}^{-}$$\mathrm{N}$ and $\mathrm{NH}_{4}{ }^{+}-\mathrm{N}$ quantities.

\section{Plant sampling and analyses}

To estimate the $\mathrm{N}$ content of the harvested crop and in the above-ground plant residues, the plants were also analysed for N. Ten potato plants were collected randomly over each experimental area. The crop density was determined by measuring the number of potato plants per $10 \mathrm{~m}$ of ten randomly selected beds in each area. The plants were divided into leaves, stems and tubers. The samples were oven dried $\left(12 \mathrm{~h}, 105^{\circ} \mathrm{C}\right)$ and their dry weight was determined. The nitrogen concentration of each plant organ was determined by using a Leco CHN900 analyzer (Kleemola and Teittinen 1996).

\section{Results}

\section{Soil profiles}

The three studied profiles in Area A had sulfidic materials in the subsoil, which started at the depth of $140 \mathrm{~cm}$ to $200 \mathrm{~cm}$ and had its average upper boundary at $170 \mathrm{~cm}$, see Table 1 . According to Soil Taxonomy (Soil Survey Staff 1999), fresh pH $>4.0$ and a decrease of soil $\mathrm{pH}$ by at least 0.5 units to values below 4.0 indicates the presence of sulfidic materials. The $\mathrm{S}_{\text {tot }}$ concentration of these horizons was, however, too low $(<0.75 \%)$ to qualify as sulfidic materials of the FAO system (FAO 1988). Morphologically, these horizons were grey and massive, indicating predominantly reduced conditions. The oxidized horizons above (80-140 $\mathrm{cm}$ ) had a $\mathrm{pH}$ of between 3.5 and 4.0, no decrease of $\mathrm{pH}$ upon incubation and a well developed structure, stabilized by plenty of iron hydroxide. The concentration of $\mathrm{SO}_{4}^{2-}-\mathrm{S}$ at $140-170 \mathrm{~cm}$ was just above $0.05 \%$ (Table 1 ). As the soils were sampled in spring, soon after the snow melt waters had leached the soil profile, higher values of $\mathrm{SO}_{4}{ }^{2-}-\mathrm{S}$ may have been measured in summer. Area A did not have a sulphuric horizon $(\mathrm{pH}<3.5$; Table 1$)$, but the criteria of the sulfic attribute of Soil Taxonomy were barely met.

Deviating substantially from Area A, Area B did not have sulfidic materials within the investigated depth $(-240 \mathrm{~cm})$. The $\mathrm{pH}$ of the incubated subsoil samples remained above 5.2. Also the concentration of $\mathrm{SO}_{4}{ }^{2-}-\mathrm{S}$ was very low throughout the two profiles sampled, and the concentrations of $S_{\text {tot }}$ 
Vol. 14 (2005): 57-69.

Table 1. The $\mathrm{pH}$ values and sulphur concentrations of soil samples taken from different depths of the experimental fields in Lapua. The concentrations of $\mathrm{SO}_{4}{ }^{2-}-\mathrm{S}$ were analysed from incubated samples.

\begin{tabular}{lcccc}
\hline $\begin{array}{l}\text { Depth } \\
\mathrm{cm}\end{array}$ & $\begin{array}{c}\mathrm{pH} \\
\text { fresh }\end{array}$ & $\begin{array}{c}\mathrm{pH} \\
\text { incubated }\end{array}$ & $\begin{array}{c}\mathrm{SO}_{4}^{2-}-\mathrm{S} \\
\%\end{array}$ & $\begin{array}{c}\text { Total S } \\
\%\end{array}$ \\
\hline Field A & & & & \\
$0-20$ & 5.7 & n.d. & n.d. & 0.05 \\
$20-50$ & 5.3 & n.d. & n.d. & 0.02 \\
$50-80$ & 4.3 & n.d. & n.d. & 0.03 \\
$80-110$ & 3.9 & n.d. & n.d. & 0.05 \\
$110-140$ & 3.9 & 3.9 & 0.015 & 0.12 \\
$140-170$ & 4.1 & 3.7 & 0.050 & 0.17 \\
$170-200$ & 4.5 & 3.7 & 0.082 & 0.26 \\
$200-240$ & 6.2 & 3.5 & 0.206 & 0.41 \\
Field B & & & & \\
$0-20$ & 6.2 & n.d. & n.d. & 0.04 \\
$20-50$ & 4.9 & n.d. & n.d. & 0.02 \\
$50-80$ & 5.0 & n.d. & n.d. & 0.01 \\
$80-110$ & 5.3 & n.d. & n.d. & 0.01 \\
$110-140$ & 5.4 & 5.2 & 0.002 & 0.01 \\
$140-170$ & 5.4 & 5.3 & 0.002 & 0.02 \\
$170-200$ & 5.4 & 5.3 & 0.002 & 0.01 \\
$200-240$ & 6.0 & 5.2 & 0.003 & 0.02 \\
\hline
\end{tabular}

n.d. $=$ not determined

in the subsoil of Area B were only $3-10 \%$ and $\mathrm{C}_{\text {tot }}$ $38-53 \%$ of those in the corresponding horizons of Area A.

In the Lapua area, soils have a cryic temperature regime (Yli-Halla and Mokma 1998). In spite of a relatively high content of organic matter, the soils were not very dark (moist colour 7.5YR 4/2, dry colour 7.5YR 6/2) and they consequently had ochric Ap horizons. According to Soil Taxonomy (Soil Survey Staff 1999) and given the requirement that acid sulphate characteristics occur within $150 \mathrm{~cm}$ of soil surface, Area A was a Sulfic Cryaquept and Area B a Typic Cryaquept. According to the FAO system (FAO 1988), both areas represented Dystric Cambisols, because the more stringent criteria of acid sulphate characteristics of the FAO system $(\mathrm{pH}<3.5$ and total $\mathrm{S}$ of sulfidic materials $>0.75 \%$ ) were not met.

\section{Total carbon and nitrogen}

The $\mathrm{C}_{\text {tot }}{ }^{-}$and $\mathrm{N}_{\text {tot }}$-concentrations, shown in each sampling layer in Table 2, indicated clearly that Field A was richer in both elements, the relative difference being largest below the depth of $50 \mathrm{~cm}$. In both fields, the amount of $\mathrm{C}_{\text {tot }}$ and $\mathrm{N}_{\text {tot }}$ varied clearly with the depth (Table 3). The amount of $\mathrm{C}_{\text {tot }}$ in the plough layer accounted for $40 \%$ of the reserves in the whole profile of 0-240 cm in Area A and $53 \%$ in Area B. The horizons of $100-240 \mathrm{~cm}$ formed $36 \%$ of $\mathrm{C}_{\text {tot }}$ in Area A and 27\% in Area B. Concerning $\mathrm{N}_{\text {tot }}$, the plough layer had only $25 \%$, while the depths below $100 \mathrm{~cm}$ had as much as $52 \%$ in the profile of the $0-240 \mathrm{~cm}$ in Area A. The corresponding proportions in Area B were 38\% and $42 \%$, respectively. The mean $\mathrm{C} / \mathrm{N}$ ratio at $0-20$ $\mathrm{cm}$ was about 23 in both fields. The ratio decreased sharply below the depth of $50 \mathrm{~cm}$ (Table 2).

\section{Mineral nitrogen}

On average, $\mathrm{N}_{\text {min }}\left(\mathrm{NO}_{3}^{-}-\mathrm{N}\right.$ and $\left.\mathrm{NH}_{4}{ }^{+}-\mathrm{N}\right)$ accounted for $1.4 \%$ and $0.8 \%$ of $\mathrm{N}_{\text {tot }}$ in the whole profile (0$240 \mathrm{~cm}$ ) in Area A and in Area B, respectively. The amount of $\mathrm{N}_{\min }$ and its fractions and their vertical distribution in the soil profile clearly differed between the fields (Table 4). There was over three times more $\mathrm{N}_{\min }$ in Field A than in Field B. In both 
Paasonen-Kivekäs, M. \& Yli-Halla, M. N and C reserves in acid sulphate and non acid sulphate soils

Table 2. Mean concentration of total carbon (C) and nitrogen $(\mathrm{N}), \mathrm{C} / \mathrm{N}$ ratio and bulk density of soil samples taken from different depths in Fields A and B at the Lapua site.

\begin{tabular}{lcccc}
\hline $\begin{array}{l}\text { Depth } \\
\mathrm{cm}\end{array}$ & $\begin{array}{c}\text { Total C } \\
\%\end{array}$ & $\begin{array}{c}\text { Total } \\
\%\end{array}$ & $\begin{array}{c}\text { C/N } \\
\text { ratio }\end{array}$ & $\begin{array}{c}\text { Bulk density } \\
\mathrm{g} \mathrm{cm}^{-3}\end{array}$ \\
\hline Field A & & & & \\
$0-20$ & 6.65 & 0.29 & 22.8 & 1.07 \\
$20-50$ & 1.92 & 0.10 & 19.5 & 1.54 \\
$50-80$ & 0.56 & 0.05 & 11.2 & 1.35 \\
$80-110$ & 0.91 & 0.09 & 10.1 & 1.31 \\
$110-140$ & 0.90 & 0.09 & 9.9 & 1.32 \\
$140-170$ & 0.86 & 0.09 & 9.5 & 1.32 \\
$170-200$ & 0.87 & 0.09 & 9.6 & 1.33 \\
$200-240$ & 0.78 & 0.08 & 9.8 & \\
Field B & & & & 1.14 \\
$0-20$ & 5.71 & 0.25 & 23.3 & 1.52 \\
$20-50$ & 1.27 & 0.06 & 21.1 & 1.46 \\
$50-80$ & 0.22 & 0.02 & 11.0 & 1.43 \\
$80-110$ & 0.22 & 0.02 & 10.9 & 1.40 \\
$110-140$ & 0.34 & 0.03 & 11.3 & 1.39 \\
$140-170$ & 0.45 & 0.04 & 11.1 & 1.42 \\
$170-200$ & 0.46 & 0.04 & 11.6 & 9.4 \\
$200-240$ & 0.38 & 0.04 & & \\
\hline
\end{tabular}

Table 3. Mean stock of total carbon $(\mathrm{C})$ and nitrogen $(\mathrm{N})$ in different depth intervals and in a $0-240 \mathrm{~cm}$ profile in Fields A and B in Lapua.

\begin{tabular}{ccc}
\hline Depth, cm & Total C, tn ha ${ }^{-1}$ & Total N, tn ha ${ }^{-1}$ \\
\hline Field A & & \\
$0-30$ & 172 & 7.8 \\
$30-50$ & 59 & 3.0 \\
$50-100$ & 46 & 4.4 \\
$100-150$ & 59 & 6.0 \\
$150-200$ & 57 & 5.9 \\
$200-240$ & 42 & 4.3 \\
$0-240$ & 435 & 31.4 \\
Field B & & \\
$0-30$ & 150 & 6.5 \\
$30-50$ & 39 & 1.8 \\
$50-100$ & 17 & 1.6 \\
$100-150$ & 24 & 2.1 \\
$150-200$ & 32 & 2.8 \\
$200-240$ & 21 & 2.3 \\
$0-240$ & 283 & 17.1 \\
\hline
\end{tabular}

fields, there was a prominent pool of $\mathrm{N}_{\min }$ in the deeper soil layers. In Area A, 75\% of the $\mathrm{N}_{\text {min }}$ reserve was at a depth of 100-240 cm. The corresponding value in Area B was 57\%.

At the depth of $0-100 \mathrm{~cm}, \mathrm{NO}_{3}^{-}-\mathrm{N}$ formed over $80 \%$ of the $\mathrm{N}_{\min }$ pool in both fields. In Field A, the amount of $\mathrm{NH}_{4}{ }^{+}-\mathrm{N}$ sharply increased and $\mathrm{NO}_{3}{ }^{-}-\mathrm{N}$ decreased below the $100-150 \mathrm{~cm}$ layer. The amount of $\mathrm{NH}_{4}{ }^{+} \mathrm{N}$ at $150-240 \mathrm{~cm}$ was $256 \mathrm{~kg} \mathrm{ha}^{-1}$, accounting for $96 \%$ of the $\mathrm{N}_{\text {min }}$ in this horizon. In Field $\mathrm{B}, \mathrm{NO}_{3}^{-}-\mathrm{N}$ remained the dominant fraction at all depth intervals, while the proportion of $\mathrm{NH}_{4}{ }^{+} \mathrm{N}$ remained below $17 \%$, even in the deepest layers. The vertical distribution of the $\mathrm{N}_{\min }$ fractions within each field gave the same type of pattern at all sampling dates.

The amount of $\mathrm{N}_{\min }$ was relatively consistent between the different sampling profiles and dates within each field. The average amount of $\mathrm{N}_{\min }$ in spring was $429 \mathrm{~kg} \mathrm{ha}^{-1}$ in Field A and $122 \mathrm{~kg} \mathrm{ha}^{-1}$ in Field B. In November, there was only $6.1 \mathrm{~kg} \mathrm{ha}^{-1}$ more $\mathrm{N}_{\min }$ at $0-240 \mathrm{~cm}$ in Field A than in May and $14.8 \mathrm{~kg} \mathrm{ha}^{-1}$ more in Field $\mathrm{B}$. The change in the quantity of $\mathrm{NH}_{4}{ }^{+}-\mathrm{N}^{-}$and $\mathrm{NO}_{3}{ }^{-} \mathrm{N}$ in Field A was 6.7 $\mathrm{kg} \mathrm{ha}^{-1}$ and $-0.6 \mathrm{~kg} \mathrm{ha}^{-1}$, respectively. In Field $\mathrm{B}$, the quantity of $\mathrm{NO}_{3}^{-}-\mathrm{N}$ increased by $23.0 \mathrm{~kg} \mathrm{ha}^{-1}$, whereas $\mathrm{NH}_{4}{ }^{+}-\mathrm{N}$ decreased by $8.2 \mathrm{~kg} \mathrm{ha}^{-1}$. The biggest changes from spring to autumn were detected at the depths below $100 \mathrm{~cm}$. The coefficient of variation $(\mathrm{CV})$ of $\mathrm{NH}_{4}{ }^{+} \mathrm{N}$ ranged from $19 \%$ to $80 \%$ within single soil layers. The lowest variation was observed in the deepest layers of Field A. On 
Vol. 14 (2005): 57-69.

Table 4. Content of ammonium, nitrate and mineral nitrogen $\left(\mathrm{NH}_{4}^{+}-\mathrm{N}, \mathrm{NO}_{3}^{-}-\mathrm{N}\right.$ and $\mathrm{N}_{\text {min }}$, respectively) in different depth intervals and in a 0-240 cm profile in Fields A and B in Lapua. Mean, minimum (min) and maximum (max) value, standard deviation (std) and number of profiles studied (n).

\begin{tabular}{|c|c|c|c|c|c|c|c|c|c|c|c|c|c|}
\hline \multirow{2}{*}{$\begin{array}{l}\text { Depth } \\
\mathrm{cm}\end{array}$} & \multicolumn{4}{|c|}{$\mathrm{NH}_{4}^{+}-\mathrm{N}, \mathrm{kg} \mathrm{ha}^{-1}$} & \multicolumn{4}{|c|}{$\mathrm{NO}_{3}^{-}-\mathrm{N}, \mathrm{kg} \mathrm{ha}^{-1}$} & \multicolumn{5}{|c|}{$\mathrm{N}_{\min }, \mathrm{kg} \mathrm{ha}^{-1}$} \\
\hline & mean & $\min$ & $\max$ & std & mean & $\min$ & $\max$ & std & mean & $\min$ & $\max$ & std & $\mathrm{n}$ \\
\hline \multicolumn{14}{|l|}{ Field A } \\
\hline $0-30$ & 4 & 1.4 & 11 & 3 & 34 & 13.1 & 56 & 14 & 38 & 17 & 57 & 13 & 10 \\
\hline $30-50$ & 2 & 0.0 & 3 & 1 & 20 & 10.2 & 38 & 11 & 23 & 12 & 40 & 11 & 10 \\
\hline $50-100$ & 7 & 1.7 & 16 & 5 & 39 & 27.5 & 73 & 13 & 45 & 29 & 89 & 17 & 10 \\
\hline $100-150$ & 40 & 15.7 & 70 & 17 & 22 & 8.3 & 33 & 8 & 61 & 48 & 88 & 12 & 10 \\
\hline $150-200$ & 106 & 68.5 & 160 & 30 & 7 & 2.0 & 24 & 6 & 114 & 74 & 165 & 33 & 10 \\
\hline $200-240$ & 150 & 98.3 & 180 & 29 & 2 & 0.2 & 11 & 3 & 152 & 100 & 180 & 29 & 10 \\
\hline $0-240$ & 309 & 185.6 & 440 & & 124 & 61.3 & 234 & & 433 & 280 & 619 & & \\
\hline \multicolumn{14}{|l|}{ Field B } \\
\hline $0-30$ & 3 & 1.2 & 7 & 2 & 15 & 10.9 & 19 & 3 & 18 & 12 & 21 & 3 & $6^{\mathrm{a}} / 7^{\mathrm{b}}$ \\
\hline $30-50$ & 2 & 0.4 & 5 & 1 & 9 & 4.9 & 18 & 5 & 11 & 5 & 20 & 5 & $6^{\mathrm{a}} / 7^{\mathrm{b}}$ \\
\hline $50-100$ & 4 & 1.1 & 7 & 2 & 23 & 16.1 & 35 & 7 & 27 & 19 & 40 & 7 & $6^{\mathrm{a}} / 7^{\mathrm{b}}$ \\
\hline $100-150$ & 3 & 0.6 & 5 & 2 & 27 & 21.4 & 31 & 4 & 29 & 22 & 33 & 4 & $6^{\mathrm{a}} / 7^{\mathrm{b}}$ \\
\hline $150-200$ & 2 & 0.0 & 4 & 2 & 25 & 19.5 & 29 & 5 & 27 & 21 & 33 & 5 & $6^{\mathrm{a}} / 7^{\mathrm{b}}$ \\
\hline $200-240$ & 3 & 0.1 & 6 & 2 & 15 & 7.7 & 20 & 5 & 18 & 14 & 22 & 4 & $6^{\mathrm{a}} / 7^{\mathrm{b}}$ \\
\hline $0-240$ & 17 & 3.4 & 34 & & 114 & 80.5 & 152 & & 130 & 93 & 169 & & \\
\hline
\end{tabular}

${ }^{\text {a }} \mathrm{NO}_{3}-\mathrm{N}$ and $\mathrm{N}_{\text {min }}$

b $\mathrm{NH}_{4}{ }^{+}-\mathrm{N}$

average, the amount of $\mathrm{NO}_{3}^{-}-\mathrm{N}$ showed more consistency at a depth of $0-200 \mathrm{~cm}$. The highest CV (165\%) was in the 200-240 cm layer in Field A, where the reserve of $\mathrm{NO}_{3}^{-}-\mathrm{N}$ was very small.

\section{Nitrogen uptake by crop}

The average fertilizer rate and $\mathrm{N}$ uptake of crops are presented in Table 5. The $\mathrm{N}$ uptake between the samples varied more within Field A (CV $40 \%$ on average) than within Field B (CV 24\% on average). The $\mathrm{N}$ content of potato stems and leaves varied from $22.6 \mathrm{~kg} \mathrm{ha}^{-1}$ to $61.9 \mathrm{~kg} \mathrm{ha}^{-1}$ one week before harvest depending on the area and year. Potato tubers stored 5-93.6 $\mathrm{kg} \mathrm{ha}^{-1}$ more $\mathrm{N}$ than the amounts applied as fertilizer $\mathrm{N}$.

\section{Depth to groundwater table}

Temporal variation of depth to groundwater table is shown in Fig. 2. Since variation across the fields was found to be small, the mean depths are pre-
Table 5. $\mathrm{N}$ fertilizer rate and mean $\mathrm{N}$ uptake by crop in Fields A and B in Lapua. Residual $\mathrm{N}=$ fertilizer $\mathrm{N}-\mathrm{N}$ in the tubers.

\begin{tabular}{lccc}
\hline & $\begin{array}{c}\text { Fertilizer rate } \\
\mathrm{kg} \mathrm{ha}^{-1}\end{array}$ & $\begin{array}{c}\mathrm{N} \text { in tubers } \\
\mathrm{kg} \mathrm{ha}^{-1}\end{array}$ & $\begin{array}{c}\text { Residual N } \\
\mathrm{kg} \mathrm{ha}^{-1}\end{array}$ \\
\hline $\begin{array}{l}\text { Field } A \\
1994\end{array}$ & 76 & 106 & -30 \\
1995 & 83 & 148 & -65 \\
Field B & & & \\
1994 & 76 & 81 & -5 \\
1995 & 83 & 177 & -94 \\
\hline
\end{tabular}

sented for each point of time. The water table in Field A usually remained shallower than in Field B due to the slightly lower topographic position and control drainage measures of Field A. Soil in Field $\mathrm{B}$ was also more effectively drained owing to its closer vicinity to the main ditch compared to Field A. Controlled drainage temporarily raised the water table and retarded its decline in Area A.

The water table periodically rose until the drain depth or higher during snow melt and rainy periods in summer and autumn. However, after the 
Paasonen-Kivekäs, M. \& Yli-Halla, $M . N$ and $C$ reserves in acid sulphate and non acid sulphate soils

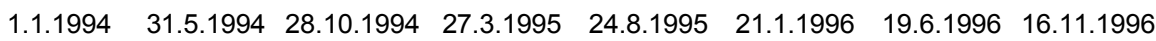

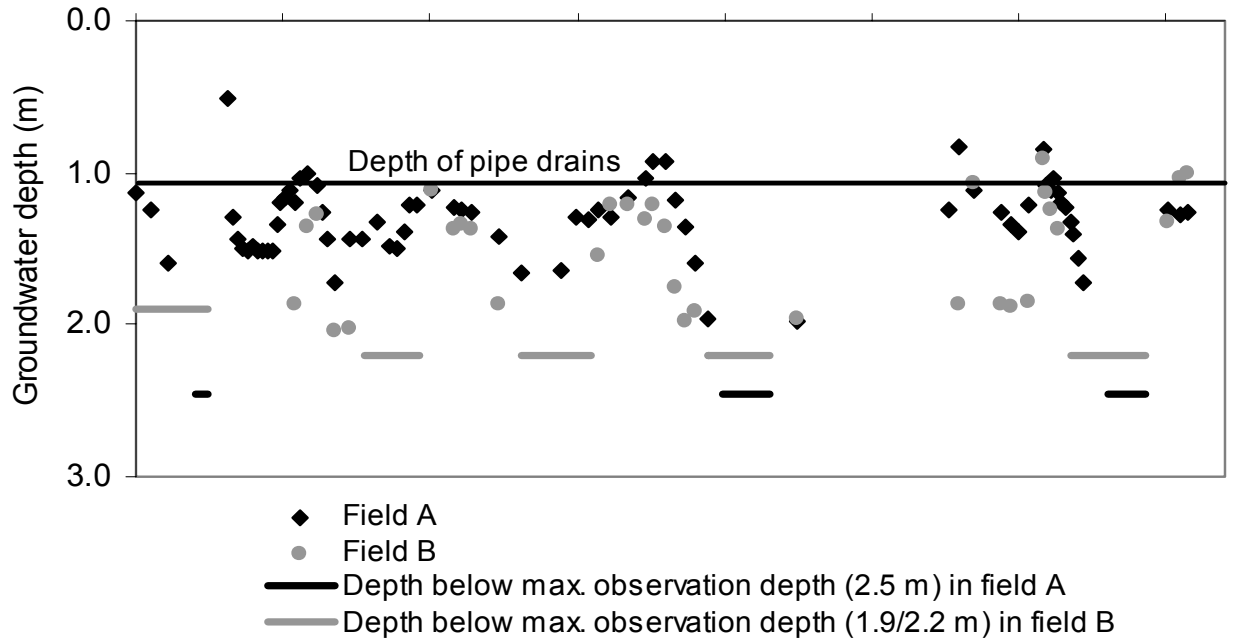

Fig. 2. Groundwater depth in Fields A and B in Lapua. No observations were available from 8 Nov 1995 until 7 April 1996. The depth of pipe drains represents the average depth in the fields.

rainfalls, the water table rapidly declined below the drain depth in both fields. From July to November 1995, the depth to water table remained below $2 \mathrm{~m}$ from the soil surface for about 80 days in Field A and about 125 days in Field B. From September to November 1996, the water table was below $2 \mathrm{~m}$ for about 65 days in Area A and 88 days in Area B. The water table even dropped to depths exceeding the depth of the deepest observation wells (2.5 m in Field A, 1.9/2.2 m in Field B, see Fig. 2).

\section{Discussion}

Field A is a typical example of cultivated Finnish AS soils. Horizons formed of non-sulfidic materials exclusively cover the sulfidic materials, which have been partly oxidized, a process accelerated by increased drainage efficiency. Leaching of water-soluble products of oxidation has resulted in a subsoil rather low in soluble salts and a $\mathrm{pH}$ at 3.54.0. Often the AS characteristics are not harsh enough or they are too deep to meet the criteria of international classification systems regarding AS soils (Yli-Halla et al. 1999). On the basis of the surveys by Erviö (1975) and Puustinen et al. (1994), these kinds of soil are typical on the coasts of Finland, the latter giving an estimate of as much as 300,000 ha AS soils in Finland. These soils may not cause problems to agriculture anymore and at the top they may not be distinguished from nonAS soils such as those of Field B, but they may still produce hazardously acidic drainage waters (Joukainen and Yli-Halla 2003). The fact that both soils of the present study have, according to the FAO classification system, the same name while the sulfidic nature of the subsoil A is not recognised, indicates the inadequacy of that system to cope with this environmentally relevant characteristic of effectively drained AS soil.

It is evident that Field $\mathrm{B}$, with its subsoil $\mathrm{pH}$ between 4.9 and 6.0, has never contained considerable concentrations of sulfide within the investigated depth. This conclusion is supported by the fact that, after oxidation of sulfide and washing out the solutes, the $\mathrm{pH}$ of the soil remains at about 4, which is not raised by leaching with water (Hartikainen and Yli-Halla 1986). Therefore we con- 
Vol. 14 (2005): 57-69.

clude that the difference between the two adjacent fields is caused by the large native heterogeneity indicated clearly in the AS soil material of Puustinen et al. (1994).

The concentration of $\mathrm{C}_{\text {tot }}$ in the subsoil in Field A was similar to the values observed at corresponding depths in, for example, the soils of Ylistaro (about 1\%, Yli-Halla 1997) and Ilmajoki (0.6$1 \%$, Joukainen and Yli-Halla 2003), both AS soils less than $100 \mathrm{~km}$ from the present experimental field, and in similar soils of Kungsängen (1.3\%, Kirchmann 1991), Ängesby and Ersnäs (0.9-1.3\%, Öborn 1989) in Sweden. These concentrations are much lower than in the subsoils of the more severe AS soils of western Finland, such as Laitila (2.53\%, Yli-Halla 1997) and Mustasaari (1.6-2.2\%, Joukainen and Yli-Halla 2003), which probably occupy a relatively small area (Yli-Halla et al. 1999). The much lower concentrations of $C_{t o t}$ in Field $B$ resembled the values $(0.1-0.5 \%)$ measured at similar depths in other soils without any AS characteristics, several examples of which can be found in Yli-Halla et al. (2000).

As compared to other AS soils with similar concentrations of organic matter in their subsoil, the concentrations of $\mathrm{N}_{\text {tot }}$ at $80-240 \mathrm{~cm}$ in Field A $(0.08-0.09 \%)$ were higher than the values at Liminka $(0.04-0.06 \%$, ) but lower than those in Ylistaro $(0.18-0.24 \%$ at $50-150 \mathrm{~cm}$, Yli-Halla $1997)$ and in Ilmajoki $(0.23-0.27 \%$ at $170-300$ $\mathrm{cm}$, Bärlund et al. 2004). Field A had clearly lower concentrations of $\mathrm{N}_{\text {tot }}$ than more severe AS soils with higher concentrations of organic matter in their subsoil, such as Mustasaari $(0.33-0.36 \%$ at 50-200 cm, Bärlund et al. 2004) or Laitila (0.32$0.58 \%$ at $50-150 \mathrm{~cm}$, Yli-Halla 1997). In Field B, the concentrations of $\mathrm{N}_{\text {tot }}(0.02-0.04 \%)$ in the subsoil were in the range of those measured in the agricultural silt and fine sand soils of Finland (0.027$0.068 \%$ at $40-100 \mathrm{~cm}$, Sippola and Yläranta 1985).

The reserves of $\mathrm{N}_{\text {tot }}$ in the $0-100 \mathrm{~cm}$ layer in both fields were similar to reserves determined in other agricultural soils in Finland. The values commonly range from 6300 to $10900 \mathrm{~kg} \mathrm{ha}^{-1}$ at $0-60$ $\mathrm{cm}$ (Sippola 1981) or up to $13300 \mathrm{~kg} \mathrm{ha}^{-1}$ at $0-100$ $\mathrm{cm}$ (Linden et al. 1992), usually being higher in clay soils than in coarse mineral soils. Indeed, the marked differences between the two soils of the present study were below $100 \mathrm{~cm}$, where the stock of $\mathrm{N}_{\text {tot }}$ of the AS soil was much greater.

The $\mathrm{N}_{\min }$ amount at $0-100 \mathrm{~cm}$ in both fields was equivalent to that of other Finnish soils. The $\mathrm{N}_{\text {min }}$ in agricultural mineral soils in spring before fertilization has generally varied from 7 to $150 \mathrm{~kg}$ $\mathrm{ha}^{-1}$ at $0-60 \mathrm{~cm}$ or $0-100 \mathrm{~cm}$ profiles (Sippola and Yläranta 1985, Leppänen and Esala 1995, Kuisma 2002), but $\mathrm{N}_{\min }$ amounts up to $290 \mathrm{~kg} \mathrm{ha}^{-1}$ at 0-60 $\mathrm{cm}$ or $0-90 \mathrm{~cm}$ in spring and autumn have also been observed in some fields (Leppänen and Esala 1995, 1999). The highest values were connected with animal manure application and cultivation of grass and vegetable crops.

Even though the $\mathrm{N}_{\text {tot }}$ concentrations in the subsoil samples were generally small, they seem to be quite accurate. This conclusion can be drawn from the small mean deviation of the replicates and the small variation of the $\mathrm{C} / \mathrm{N}$ ratio in the subsoil samples. The biggest inaccuracy of this study is probably the estimation of the BD values of the subsoil with the help of the Howard et al. (1995) equation. Indeed, that equation gave much lower BD values than were actually measured for the soil samples taken from $40-50 \mathrm{~cm}$, probably compacted by agricultural operations. However, the close match between the calculated and measured BD values of the soil samples taken from $0-30 \mathrm{~cm}$ and $60-70$ $\mathrm{cm}$ gives us confidence in the calculated values of the deeper layers, which are not affected by compaction. We therefore think that the estimates of the $\mathrm{C}_{\text {tot }}$ and $\mathrm{N}_{\text {tot }}$ in the deeper layers are reasonable.

In both years of the experiment, the $\mathrm{N}$ uptake by potato tubers was higher than the amount of $\mathrm{N}$ fertilizers applied, an observation also made in other experiments (Kuisma 2002). Consequently, fertilization does not explain the substantial pool of $\mathrm{N}_{\text {min }}$ in the subsoil. Moreover, the fields were managed similarly. We therefore conclude that the fact that there was a higher $\mathrm{N}_{\text {min }}$ pool in Field A than in Field B is explained by the larger amount of organic matter and organic $\mathrm{N}$. The fact that the $\mathrm{C} / \mathrm{N}$ ratio was clearly below 20 at $50-240 \mathrm{~cm}$ in both fields indicates a net mineralization tendency 
Paasonen-Kivekäs, M. \& Yli-Halla, M. N and C reserves in acid sulphate and non acid sulphate soils

leading to an accumulation of $\mathrm{N}_{\min }$ (Stevenson and Cole 1999). These horizons have been continuously waterlogged before agricultural drainage, which probably enhances the present $\mathrm{N}$ mineralization by providing aeration of subsoil. The decline of the water table well below the drains for several weeks in summer and autumn has also been observed in other studies of AS soils of the region (Joukainen and Yli-Halla 2003). The decline at the Lapua site is attributed to low precipitation, evapotranspiration and deep percolation to the neighbouring open channel. The oxidised horizons in the fields have prominent iron-hydroxidelined cracks and remnant root channels that substantially increase hydraulic conductivity of the fine textured soils. A rough estimate of annual $\mathrm{N}$ mineralization is $1.5-3.5 \%$ of the amount of organic or total N (Brady and Weil 1999). In Finland, $\mathrm{N}$ mineralization at $0-100 \mathrm{~cm}$ was about $0.6 \%$ of $\mathrm{N}_{\text {tot }}$ in silty clay soil during the growing season of barley (Sippola 1986). These results correspond well with ours in terms of the ratio of the stocks of $\mathrm{N}_{\text {min }}$ and $\mathrm{N}_{\text {tot }}$.

$\mathrm{NO}_{3}{ }^{-} \mathrm{N}$ is usually the dominant $\mathrm{N}_{\text {min }}$ fraction in well-drained neutral-to-slightly-acid mineral soils. The predominance of $\mathrm{NO}_{3}^{-}-\mathrm{N}$ at $0-100 \mathrm{~cm}$ in Field $A$ and at $0-240 \mathrm{~cm}$ in Field B reflects favourable conditions for the nitrifying micro-organisms. The abundant accumulation of $\mathrm{NH}_{4}^{+}-\mathrm{N}$ below $100 \mathrm{~cm}$ in Field A indicates retarded nitrification. It can be attributed to 1) the higher water table, 2) a higher content of organic matter consuming oxygen during decomposition, 3) the strongly acidic conditions in the aerobic subsoil and, consequently, high concentrations of dissolved metals such as $\mathrm{Al}, 4$ ) the incidence of $\mathrm{H}_{2} \mathrm{~S}$ in the reduced subsoil and 5) low soil temperature (e.g., Paul and Clark 1989, Scheffer and Schachtschabel 2002).

In spite of the periodically deep groundwater table, the diffusion rate of oxygen into the deepest horizons studied is assumed to be slow due to the massive soil structure and high water retention capacity of the silt soil. Nitrification is one of the most $\mathrm{pH}$-sensitive soil reactions; the minimum $\mathrm{pH}$ for the reaction to occur is about 4.5. However, in acid soils $(\mathrm{pH}<4)$, production of $\mathrm{NO}_{3}^{-}-\mathrm{N}$ has been reported to occur probably due to heterotrophic ni- trifiers (Paul and Clark 1989). They are more acid tolerant than autotrophic organisms, but the rate of nitrification is much lower. The impact of the low $\mathrm{pH}$ alone on nitrification in Field A was not clear because high amounts of $\mathrm{NO}_{3}^{-}-\mathrm{N}$ also occurred in horizons which had a $\mathrm{pH}<4.5$.

Conversion of soil organic $\mathrm{N}$ to $\mathrm{NH}_{4}{ }^{+} \mathrm{N}$ has been observed even at $2^{\circ} \mathrm{C}$, whereas very little $\mathrm{NO}_{3}{ }^{-} \mathrm{N}$ is formed below $+5^{\circ} \mathrm{C}$. The rates clearly increase above $+15-20^{\circ} \mathrm{C}$ (Karvonen 1992, Stevenson and Cole 1999). In Ylistaro, less than 100 $\mathrm{km}$ from the present experimental site, the average monthly soil temperature in the period 1971-1990 at $100 \mathrm{~cm}$ in summer was $>10^{\circ} \mathrm{C}$ in only three months and never at $200 \mathrm{~cm}$ (Heikinheimo and Fougstedt 1992). At both depths, the soil temperature was $<5.0^{\circ} \mathrm{C}$ for six months with minimum monthly values of $0.4^{\circ} \mathrm{C}$ at $100 \mathrm{~cm}$ and $2.8^{\circ} \mathrm{C}$ at $200 \mathrm{~cm}$. The temperature conditions indicate that release of mineral $\mathrm{N}$ probably proceeds in the bottom layers of the studied soils at relatively low rates throughout the year.

In spite of the fact that $\mathrm{NH}_{4}{ }^{+}-\mathrm{N}$ occurred in the subsoil of Field A in larger quantities than found usually, it represented less than $0.2 \mathrm{cmol} \mathrm{kg}^{-1}$. That is a negligible amount when compared to the estimated cation exchange capacity of about $14 \mathrm{cmol}$ $\mathrm{kg}^{-1}$ (see the Ylistaro soil in Yli-Halla 1997). This calculation thus shows that the subsoil of Field A was in no way saturated with $\mathrm{NH}_{4}{ }^{+}-\mathrm{N}$, suggesting that $\mathrm{NH}_{4}{ }^{+} \mathrm{N}$ can to a large extent be retained by soil. In contrast to $\mathrm{NH}_{4}^{+}, \mathrm{NO}_{3}{ }^{-}$ions are highly mobile and move readily via drainage water and deep percolation. A major part of $\mathrm{NO}_{3}^{-}-\mathrm{N}$ leached below the drain depth in Field A may be reduced to gaseous $\mathrm{N}$ forms $\left(\mathrm{N}_{2} \mathrm{O}\right.$ and $\left.\mathrm{N}_{2}\right)$ by denitrification. In the deeper horizons, low aeration and an ample supply of soluble organic $\mathrm{C}$ form favourable conditions for the reaction (Firestone 1982).

\section{Conclusions}

This study dealt with $\mathrm{C}_{\text {tot }}, \mathrm{N}_{\text {tot }}$ and $\mathrm{N}_{\text {min }}$ reserves in an agricultural AS soil in western Finland as com- 
Vol. 14 (2005): 57-69.

pared to a non AS soil. Despite the small amount of research material, $\mathrm{C}_{\mathrm{tot}}$ and $\mathrm{N}_{\text {tot }}$ of the experimental site were in the ranges commonly found in AS soils in Finland. We therefore believe that we can also make meaningful conclusions and generalizations on the basis of the $\mathrm{N}_{\text {min }}$ results of this study.

A large stock of $\mathrm{N}_{\min }$ occurred below the depth of $100 \mathrm{~cm}$ particularly in the AS soil, but also in the non AS soil. These depths are usually ignored in soil $\mathrm{N}$ investigations. This storage may be insignificant for crops, but can have an environmental impact releasing soluble $\mathrm{N}$ into drain pipes and deep groundwater. The release of $\mathrm{N}_{\min }$ from the deeper soil layers is expected to contribute much more to the $\mathrm{N}_{\text {min }}$ load of watercourses than losses from fertilization. Significant amounts of $\mathrm{N}_{\min }$ seem to be released from the large reserves of organic matter, particularly in previously poorly drained AS soils, due to their high organic $\mathrm{N}$ content and low $\mathrm{C} / \mathrm{N}$ ratio. The persistence and transport of $\mathrm{NH}_{4}{ }^{+} \mathrm{N}$, the dominant form of $\mathrm{N}_{\min }$ in the subsoil of AS soil, need to be examined in further studies. Measurements of $\mathrm{N}_{\min }$ in different types of non AS soils are needed to further explain the differences in $\mathrm{N}$ losses between AS soils and non AS soils.

Acknowledgements. The authors thank the laboratory staff of the two participating institutions for the soil analyses. Thanks are extended to Dr. Jouko Kleemola and Mr. Matti Teittinen for crop analyses carried out at the Department of Plant Production at the University of Helsinki. Mr. Kalevi Pelanteri, the farmer of the experimental fields, is acknowledged for the groundwater observations and co-operation. The contribution of Prof. Pertti Vakkilainen and Prof. Tuomo Karvonen to the research project of the Lapua site is appreciated. The research was supported by funding from the Finnish Field Drainage Foundation.

\section{References}

Bärlund, I., Tattari, S., Yli-Halla, M. \& Åström, M. 2004. Effects of sophisticated drainage techniques on groundwater level and drainage water quality on acid sulphate soils - Final report of the HAPSU project. The Finnish Environment 732. 68 p. Updated 3 Nov 2004. Cited 10
Nov 2004. Available on the Internet: http://www.environment.fi/publications.

Blake, G.R. 1985a. Bulk density. In: Black, C.A. et al. (eds.). Methods of soil analysis, Part I. American Society of Agronomy, Madison, WI, USA. Agronomy Monographs 9. p. 374-390.

Blake, G.R. 1985b. Particle density. In: Black, C.A. et al. (eds.). Methods of soil analysis, Part I. American Society of Agronomy, Madison, WI, USA. Agronomy Monographs 9. p. 371-373.

Brady, N.C. \& Weil, R.R. 1999. The nature and properties of soils. Prentice Hall. 881 p.

Emteryd, O. 1989. Chemical and physical analysis of inorganic nutrients in plant, soil, water and air. Sveriges Lantbruksuniversitet, Institut för skoglig ståndortslära. Stencil No. 10. Umeå. p. 71-73.

Erviö, R. 1975. Kyrönjoen vesistöalueen rikkipitoiset viljelysmaat. Summary: Cultivated sulphate soils in the drainage basin of river Kyrönjoki. Journal of the Scientific Agricultural Society of Finland 47: 550-561.

FAO 1988. FAO/Unesco soil map of the world. Revised legend, with corrections. World Soil Resources Report 60. FAO, Rome. Reprinted as Technical Paper 20, ISRIC, Wageningen, The Netherlands, 1994. 140 p.

Firestone, M.K. 1982. Biological denitrification. In: Stevenson, F.J. (ed.). Nitrogen in agricultural soils. American Society of Agriculture. Agronomy 22: 289-326.

Hansen, K. 1959. The terms Gyttja and Dy. Hydrobiologia 13: 309-315.

Hartikainen, H. \& Yli-Halla, M. 1986. Oxidation-induced leaching of sulphate and cations from acid sulphate soils. Water, Air and Soil Pollution 27: 1-13.

Heikinheimo, M. \& Fougstedt, B. 1992. Tilastoja maan lämpötilasta Suomessa 1971-1990. Statistics of soil temperature in Finland 1971-1990. Meteorological Publications 22. $75 \mathrm{p}$.

Howard, P.J.A., Loveland, P.J., Bradley, R.I., Dry, F.T., Howard, D.M. \& Howard, D.C. 1995. The carbon content of soil and its geographical distribution in Great Britain. Soil Use and Management 11:9-15.

Joukainen, S. \& Yli-Halla, M. 2003. Environmental impacts and acid loads from deep sulfidic layers of two welldrained acid sulfate soils in western Finland. Agriculture, Ecosystems and Environment 95: 297-309.

Karvonen, H. 1992. Lämpötilan vaikutus typen mineralisaatioon maaperässä. Abstract: Effect of temperature on soil nitrogen mineralization. Helsinki University of Technology, Department of Civil Engineering and Surveying, MSc thesis. $107 \mathrm{p}$.

Kauppi, P.E., Posch, M, Hänninen, P., Henttonen, H.M., Ihalainen, A., Lappalainen, E., Starr, M. \& Tamminen, P. 1997. Carbon reservoirs in peatlands and forests in the boreal regions of Finland. Silva Fennica 31: 1325.

Kirchmann, H. 1991. Properties and classification of soils of the Swedish long-term fertility experiments. I. Sites at Fors and Kungsängen. Acta Agriculturae Scandinavica 41: 227-242.

Kleemola, J. \& Teittinen, M. 1996. Satotuloksia säätösalaojituksen ja padotuskastelun koekentiltä 1994-1995 (Crop yield results from the field experiments under controlled drainage and subirrigation in 1994-1995, in 
Paasonen-Kivekäs, M. \& Yli-Halla, M. N and C reserves in acid sulphate and non acid sulphate soils

Finnish). Salaojituksen tutkimusyhdistys ry:n tiedote 21: 12-19.

Kortelainen, P. \& Pajunen, H. 2000. Carbon store in Finnish lake sediments: a preliminary estimate. Geological Survey of Finland, Special Paper 29: 83-92.

Kuisma, P. 2002. Split nitrogen fertilization with irrigation on potato. Agricultural and Food Science in Finland 11: 59-74.

Leppänen, A. \& Esala, M. 1995. Keväisen mineraalityppianalyysin käyttö lannoitustarpeen ennustamisessa (Mineral $\mathrm{N}$ analysis in spring for predicting fertilization, in Finnish). Maatalouden tutkimuskeskus, Tiedote 1/95. $29 \mathrm{p}$.

Leppänen, A. \& Esala, M. 1999. Keväisen mineraalityppianalyysin käyttö lannoitustarpeen ennustamiseen (Mineral $\mathrm{N}$ analysis in spring for predicting fertilization, in Finnish). Maatalouden tutkimuskeskuksen julkaisuja $65.25 \mathrm{p}$.

Linden, B., Lyngstad, I., Sippola, J., Søegaard, K. \& Kjellerup, V. 1992. Nitrogen mineralization during the growing season. 1. Contribution to the nitrogen supply of spring barley. Swedish Journal of Agricultural Research 22: 3-12.

Liski, J. \& Westman, C.J. 1997. Carbon storage in forest soil of Finland. II. Size and regional patterns. Biogeochemistry 36: 261-274.

MacLean, E.O. 1984. Soil pH and lime requirements. In: Page, A.L. (ed.). Methods of soil analysis, Part 2. American Society of Agronomy, Madison, WI, USA. Agronomy Monographs 9. p. 199-224.

Minkkinen, K. 1999. Effect of forestry drainage on the carbon balance and radiative forcing of peatlands in Finland. PhD thesis. Department of Forest Ecology, University of Helsinki. $42 \mathrm{p}$.

Öborn, I. 1989. Properties and classification of some acid sulphate soils in Sweden. Geoderma 45: 197-219.

Paasonen-Kivekäs, M., Karvonen, T. \& Vakkilainen, P. 1997. Säätöojitus Lapuan koealueella, mittaukset ja aineisto 1993-1997 (Controlled drainage at the Lapua site. Measurements and data 1993-1997, in Finnish). Vesitalouden laboratorion monistesarja 1997:3. Teknillinen korkeakoulu, Otaniemi. $87 \mathrm{p}$.

Paul, E.A. \& Clark, F.E. 1989. Soil microbiology and biochemistry. Academic Press. 275 p.

Purokoski, P. 1958. Die schwefelhaltigen Tonsedimente in dem Flachlandgebiet von Liminka im Lichte chemischer Forschung. Agrogeological Publications 70.88 p.

Puustinen, M., Merilä, E., Palko, J. \& Seuna, P. 1994. Kuivatustila, viljelykäytäntö ja vesistökuormitukseen vaikuttavat ominaisuudet Suomen pelloilla. Summary: Drainage level, cultivation practices and factors affecting load on waterways in Finnish farmland. National Board of Waters and Environment. Report 198. 323 p.
Rekolainen, S. 1989. Phosphorus and nitrogen load from forest and agricultural areas in Finland. Aqua Fennica 19: 95-107.

SFS 3044. Metal content of water, sludge and sediment determined by atomic absorption spectroscopy, atomization in flame. General principles and guidelines. Finnish Standards Association, 1980. 8 p.

Scheffer, F. \& Schachtschabel, P. 2002. Lehrbuch der Bodenkunde. Spektrum. 593 p.

Sippola, J. 1981. Viljelymaan typpivarat (Nitrogen reserves in agricultural soil, in Finnish). Koetoiminta ja käytäntö 39: 51.

Sippola, J. 1986. Maan typpivarojen mineraloituminen (Mineralization of soil nitrogen, in Finnish). Koetoiminta ja käytäntö 43: 67.

Sippola, J. \& Yläranta, T. 1985. Mineral nitrogen reserves in soil and nitrogen fertilization of barley. Annales Agriculturae Fenniae 24: 125-129.

Soil Survey Staff 1999. Soil taxonomy. A basic system of soil classification for making and interpreting soil surveys. USDA-NRCS. Agriculture Handbook 436. 2nd ed. US Government Printing Office, Washington, DC. $869 \mathrm{p}$.

Stevenson, F.J. \& Cole, M.A. 1999. Cycles of soil. Carbon, nitrogen, phosphorus, sulfur, micronutrients. Wiley. 418 p.

Vomocil, J.A. 1985. Porosity. Bulk Density. In: Black, C.A. et al. (eds.). Methods of soil analysis, Part I. American Society of Agronomy, Madison, WI, USA. Agronomy Monographs 9. p. 299-314.

Vuorenmaa, J., Rekolainen, S., Lepistö, A., Kenttämies, K. \& Kauppila, P. 2002. Losses of nitrogen and phosphorus from agricultural and forest areas in Finland during the 1980s and 1990s. Environmental Monitoring and Assesment 76: 213-248.

Wiklander, L., Hallgren, G., Brink, N. \& Jonsson, E. 1950. Studies on gyttja soils, II. Some characteristics of two profiles from northern Sweden. Annales of the Royal Agricultural College of Sweden 32: 439-475.

Yli-Halla, M. 1997. Classification of acid sulphate soils of Finland according to Soil Taxonomy and the FAO/ Unesco legend. Agricultural and Food Science in Finland 6: 247-258.

Yli-Halla, M. \& Mokma, L. 1998. Soil temperature regimes in Finland. Agricultural and Food Science in Finland 7: 507-512.

Yli-Halla, M., Mokma, L., Peltovuori, T. \& Sippola, J. 2000. Suomalaisia maaprofiileja. Agricultural soil profiles in Finland and their classification. Publications of Agricultural Research Centre of Finland. Series A 78. 104 p.

Yli-Halla, M., Puustinen, M. \& Koskiaho, J. 1999. Area of cultivated acid sulfate soils in Finland. Soil Use and Management 15: 62-67. 
Vol. 14 (2005): 57-69.

\title{
SELOSTUS
}

\section{Happaman sulfaattimaan typpi- ja hiilivarat}

\author{
Maija Paasonen-Kivekäs ja Markku Yli-Halla \\ Teknillinen korkeakoulu ja Maa- ja elintarviketalouden tutkimuskeskus (MTT)
}

Tavanomaisten viljelymaiden hiilestä ja typestä valtaosa on sitoutuneena muokkauskerroksen orgaaniseen ainekseen. Happamissa sulfaattimaissa on melko runsaasti orgaanista ainesta myös muokkauskerroksen alapuolella. Tehokkaasti kuivatetuissa maissa näistä varoista voi mineraloitua melkoisesti typpeä maan toistuvan kuivumisen ja kostumisen seurauksena. Tässä tutkimuksessa verrattiin Lapualla sijaitsevan happaman sulfaattimaan ja vieressä sijainneen lajitekoostumukseltaan samanlaisen tavanomaisen maan hiili- ja typpivarojen määrää ja mineraalitypen (ammonium- ja nitraattityppi) esiintymistä. Molemmilla pelloilla oli viljelty pitkään perunaa, ja satojen typen otto oli poikkeuksetta runsaampaa kuin typpilannoitus. Maaprofiilit tutkittiin kerroksittain 240 cm:n syvyyteen saakka. Sulfaattimaalla 20-240 cm:n välisissä maakerroksissa oli 292 tonnia hiiltä ja 25 tonnia typpeä hehtaaria kohti, kun tavanomaisessa maassa vastaavalla syvyydellä oli hiiltä 152 tonnia ja typpeä 11 tonnia hehtaaria kohti. Syksyllä sulfaattimaassa oli mi- neraalityppeä $435 \mathrm{~kg} / \mathrm{ha}$ ja tavanomaisessa maassa 137 $\mathrm{kg} / \mathrm{ha}$. Typen arveltiin mineraloituneen pääasiassa maan orgaanisesta aineksesta. Valtaosa sulfaattimaan mineraalitypestä oli ammoniummuodossa, kun taas tavanomaisessa maassa vapautunut typpi oli nitrifioitunut nitraattitypeksi. Ammoniumtypen runsauden sulfaattimaassa arvellaan olevan seurausta ainakin maan suuremmasta vesipitoisuudesta ja heikommasta ilmanvaihdosta, alhaisemmasta $\mathrm{pH}$ :sta ja runsaammasta liukoisten metallien pitoisuudesta. Tutkimuksen päätulos oli havainto siitä, että etenkin sulfaattimaan syvemmissä kerroksissa, ja myös tavanomaisella maalla, voi esiintyä suuria mineraalityppimääriä, jotka voivat kuormittaa pinta- ja pohjavesiä tai haihtua kaasumaisina typpiyhdisteinä. Nämä mineraalitypen varat ovat tähän asti jääneet huomaamatta, koska maanäytteet typpimäärityksiä varten otetaan yleensä korkeintaan metrin syvyyteen saakka. 